\title{
Eurotiumins A-E, Five New Alkaloids from the Marine-Derived Fungus Eurotium sp. SCSIO F452
}

\author{
Wei-Mao Zhong ${ }^{1,2}{ }^{\circledR}$, Jun-Feng Wang ${ }^{1}$, Xue-Feng Shi ${ }^{1}$, Xiao-Yi Wei ${ }^{3}$, Yu-Chan Chen ${ }^{4}$, \\ Qi Zeng ${ }^{1,2}$, Yao Xiang ${ }^{1,2}$, Xia-Yu Chen ${ }^{1,2}{ }^{,}$Xin-Peng Tian ${ }^{1}$, Zhi-Hui Xiao ${ }^{1}$, Wei-Min Zhang ${ }^{4}$, \\ Fa-Zuo Wang $1, *(1)$ and Si Zhang ${ }^{1, *}$ \\ 1 CAS Key Laboratory of Tropical Marine Bio-Resources and Ecology, RNAM Center for Marine Microbiology, \\ Guangdong Key Laboratory of Marine Materia Medica, South China Sea Institute of Oceanology, \\ Chinese Academy of Sciences, 164 West Xingang Road, Guangzhou 510301, China; \\ wmzhong@scsio.ac.cn (W.-M.Z.); wangjunfeng@scsio.ac.cn (J.-F.W.); shixuefeng@scsio.ac.cn (X.-F.S.); \\ 18489875310@163.com (Q.Z.); xy920412@sina.cn (Y.X.); xychen1994@gmail.com (X.-Y.C.); \\ xinpengtian@scsio.ac.cn (X.-P.T.); xzh@scsio.ac.cn (Z.-H.X.) \\ 2 University of Chinese Academy of Sciences, 19 Yuquan Road, Beijing 100049, China \\ 3 Key Laboratory of Plant Resources Conservation and Sustainable Utilization, South China Botanical Garden, \\ Chinese Academy of Sciences, Guangzhou 510650, China; wxy@scbg.ac.cn \\ 4 State Key Laboratory of Applied Microbiology Southern China, Guangdong Provincial Key Laboratory of \\ Microbial Culture Collection and Application, Guangdong Open Laboratory of Applied Microbiology, \\ Guangdong Institute of Microbiology, 100 Central Xianlie Road, Guangzhou 510070, China; \\ chenyc@gdim.cn (Y.-C.C.); wmzhang@gdim.cn (W.-M.Z.) \\ * Correspondence: wangfazuo@scsio.ac.cn (F.-Z.W.); zhsimd@scsio.ac.cn (S.Z.); \\ Tel.: +86-020-3406-3746 (F.-Z.W.)
}

Received: 25 March 2018; Accepted: 18 April 2018; Published: 21 April 2018

\begin{abstract}
Three new prenylated indole 2,5-diketopiperazine alkaloids (1-3) with nine known ones (5-13), one new indole alkaloid (4), and one new bis-benzyl pyrimidine derivative (14) were isolated and characterized from the marine-derived fungus Eurotium sp. SCSIO F452. 1 and 2, occurring as a pair of diastereomers, both presented a hexahydropyrrolo[2,3- $b$ ]indole skeleton. Their chemical structures, including absolute configurations, were elucidated by 1D and 2D NMR, HRESIMS, quantum chemical calculations of electronic circular dichroism, and single crystal X-ray diffraction experiments. Most isolated compounds were screened for antioxidative potency. Compounds 3, 5, 6, $7,9,10$, and 12 showed significant radical scavenging activities against $\mathrm{DPPH}$ with $\mathrm{IC}_{50}$ values of 13 , $19,4,3,24,13$, and $18 \mu \mathrm{M}$, respectively. Five new compounds were evaluated for cytotoxic activities.
\end{abstract}

Keywords: prenylated indole alkaloid; benzyl pyrimidine; antioxidative and cytotoxic activities; marine fungi

\section{Introduction}

Prenylated indole 2,5-diketopiperazines (DKPs) constitute a significant class of densely functionalized structures characterized by condensation of two $\alpha$-amino acids, generally featuring a reverse prenyl moiety at $\mathrm{C}-2$ of the indole nucleus. They are widely distributed in fungi, especially in the genera Aspergillus, Penicillium, and Eurotium [1-3]. Interest in indole 2,5-DKPs is due to their significant biological activities, such as antibacterial [4], antiviral [5], anticancer [6], immunomodulatory [7], and $\alpha$-glucosidase inhibitory activities [8]. Specifically, Plinabulin, a synthetic analog of the natural DKP product halimide from marine-derived Aspergillus sp. CNC-139, has entered phase-III clinical study for the treatment of non-small cell lung cancer $[9,10]$. In the course of our continuing investigation on marine fungi [11,12], a further chemical investigation was performed on 
Eurotium sp. SCSIO F452, which was isolated from a South China Sea sediment sample and found to be producing DKPs [13]. Careful chemical examination led to the isolation and characterization of three new DKPs (1-3) along with nine known ones (5-13), one new prenylated indole alkaloid (4), and one new bis-benzyl pyrimidine derivative (14). Herein, we report the isolation, structure elucidation, antioxidative, and cytotoxic activities of these compounds.

\section{Results}

A $30 \mathrm{~L}$ fermentation broth of marine-derived fungus Eurotium sp. SCSIO F452 was extracted three times with ethyl acetate at room temperature. The solvent was evaporated in vacuo to produce a crude extract. Subsequent fractionation by various chromatographic methods including column chromatography (CC) over silica gel, octadecylsilyl silica gel (ODS), and high performance liquid chromatography (HPLC) yielded compounds 1-14 (Figure 1).

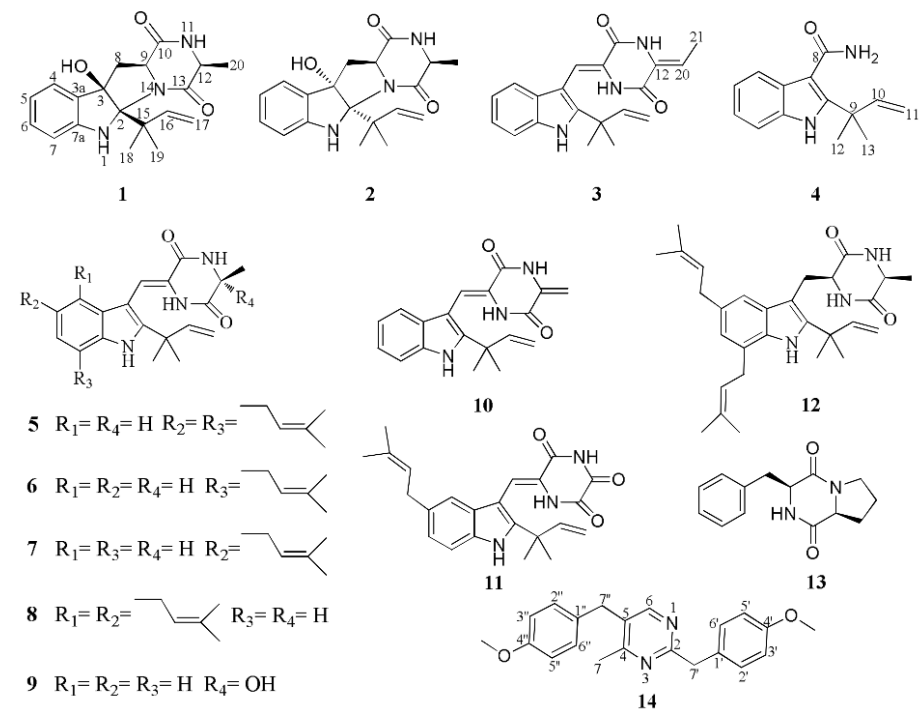

Figure 1. Chemical structures of compounds 1-14.

Compound 1 was isolated as white crystals. Its molecular formula was determined as $\mathrm{C}_{19} \mathrm{H}_{23} \mathrm{~N}_{3} \mathrm{O}_{3}$ by the positive HRESIMS $\left(\mathrm{m} / \mathrm{z} 342.1816[\mathrm{M}+\mathrm{H}]^{+}\right.$, calcd for 342.1812), indicating an index of hydrogen deficiency of 10. Its IR spectrum suggested the presence of hydroxyl and amine groups (3366, $3312 \mathrm{~cm}^{-1}$ ) and carbonyl functionalities $\left(1684,1668 \mathrm{~cm}^{-1}\right)$. The ${ }^{1} \mathrm{H}$ NMR (Table 1) spectrum of 1 recorded in acetone- $d_{6}$ showed three methyls at $\delta_{\mathrm{H}} 1.27(\mathrm{~s}), 1.29(\mathrm{~s}), 1.33(\mathrm{~d}, J=6.9 \mathrm{~Hz})$, one aliphatic methylene at $\delta_{\mathrm{H}} 2.56(\mathrm{dd}, J=12.7,7.6 \mathrm{~Hz})$ and $2.76(\mathrm{dd}, J=12.7,11.2 \mathrm{~Hz})$, two aliphatic methines at $\delta_{\mathrm{H}} 3.73(\mathrm{dd}, J=11.2,7.6 \mathrm{~Hz})$ and $\delta_{\mathrm{H}} 3.91(\mathrm{q}, J=6.9 \mathrm{~Hz})$, four aromatic protons at $\delta_{\mathrm{H}} 6.75$ (overlap), 6.76 (overlap), $7.12(\mathrm{td}, J=7.6,1.2 \mathrm{~Hz}), 7.28(\mathrm{~d}, J=7.6 \mathrm{~Hz})$, three exchangeable protons at $\delta_{\mathrm{H}} 4.49(\mathrm{~s})$, $6.53(\mathrm{~s}), 7.16(\mathrm{br} \mathrm{s})$, and three olefinic proton resonances at $\delta_{\mathrm{H}} 4.90(\mathrm{dd}, J=10.9,1.5 \mathrm{~Hz}), 4.98(\mathrm{dd}, J=17.7$, $1.2 \mathrm{~Hz}), 6.36(\mathrm{dd}, J=17.6,10.9 \mathrm{~Hz})$ suggesting the existence of a monosubstituted double bond. The ${ }^{13} \mathrm{C}$ NMR (Table 1) and DEPT revealed the presence of 19 carbon resonances, including three methyls, two methylenes (one olefinic carbon), seven methines (five olefinic carbons), and seven quaternary carbons (one oxygenated carbon, one nitrogenated carbon, two amide groups, two olefinic carbons, and one quaternary carbon). By the heteronuclear single quantum coherence (HSQC) spectrum, all proton resonances were unambiguously assigned to their respective carbons except for the exchangeable protons. All the above data suggested that 1 possessed a hexahydropyrrolo[2,3- $b$ ]indole skeleton, showing high similarities with cyclo-C3 $\beta$-dimethylallyl-L-Trp-L-Ala [14], except that the dimethylallyl group was substituted at C-2 and a hydroxyl group was located at C-3 in 1 . This was supported by the heteronuclear multiple bond correlation (HMBC) correlations (Figure 2) from H-16 $\left(\delta_{\mathrm{H}} 6.36\right)$, 
$\mathrm{H}_{3}-18\left(\delta_{\mathrm{H}} 1.27\right)$, and $\mathrm{H}_{3}-19\left(\delta_{\mathrm{H}} 1.29\right)$ to $\mathrm{C}-2\left(\delta_{\mathrm{C}} 92.4\right)$, and from OH-3 $\left(\delta_{\mathrm{H}} 4.49 \mathrm{~s}\right)$ to $\mathrm{C}-3\left(\delta_{\mathrm{C}} 89.4\right), \mathrm{C}-3 \mathrm{a}$ $\left(\delta_{\mathrm{C}} 132.2\right)$, and $\mathrm{C}-8\left(\delta_{\mathrm{C}} 36.4\right)$. The relative configuration of 1 was determined by nuclear Overhauser effect spectroscopy (NOESY) correlations (Figure 2). The NOE correlations of H-9 $\left(\delta_{\mathrm{H}} 3.73\right)$ with $\mathrm{H}-8 \mathrm{~b}\left(\delta_{\mathrm{H}} 2.56\right)$ and $\mathrm{H}-12\left(\delta_{\mathrm{H}} 3.91\right)$ indicated that they were located at the same side as $\alpha$-orientation. Furthermore, the NOE correlations of $\mathrm{H}_{3}-18$ and $\mathrm{H}_{3}-19$ with $\mathrm{OH}-3$ and $\mathrm{H}-8 \mathrm{a}\left(\delta_{\mathrm{H}} 2.76\right)$ led to their cofacial assignment as $\beta$-orientation. On the basis of the above relative configuration analysis, $\mathbf{1}$ had only one pair of enantiomers $(2 S, 3 R, 9 S, 12 S-\mathbf{1}$ and $2 R, 3 S, 9 R, 12 R-\mathbf{1})$. The quantum chemical calculation study for electronic circular dichroism (ECD) was conducted to determine its absolute configuration using time-dependent density-functional theory (TDDFT) method. Consequently, the calculated ECD for $2 S, 3 R, 9 S, 12 S-\mathbf{1}$ showed good agreement with the experimental ECD of $\mathbf{1}$ (Figure 3), which allowed the assignment of the absolute configuration of 1 as $2 S, 3 R, 9 S, 12 S$. Delightedly, a single crystal of 1 suitable for X-ray diffraction (Figure 4) was obtained from methanol. The final refinement on the $\mathrm{Cu}$ $\mathrm{K} \alpha$ data with a good Flack parameter 0.04(6) unambiguously confirming the absolute stereochemistry to be $2 S, 3 R, 9 S, 12 S$, which was consistent with the calculated ECD result. Thus, the structure of 1 was assigned as $2 S, 3 R, 9 S, 12 S$-cyclo-2-dimethylallyl-3-hydroxy-L-Trp-L-Ala (Figure 1) and named eurotiumin A.

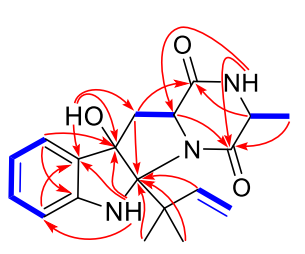

$-{ }^{1} \mathrm{H}-{ }^{1} \mathrm{H} \operatorname{COSY}$

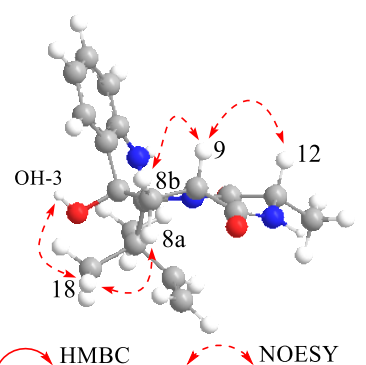

Figure 2. Key ${ }^{1} \mathrm{H}^{-1} \mathrm{H}$ COSY, HMBC, and NOESY correlations of compound $\mathbf{1}$.

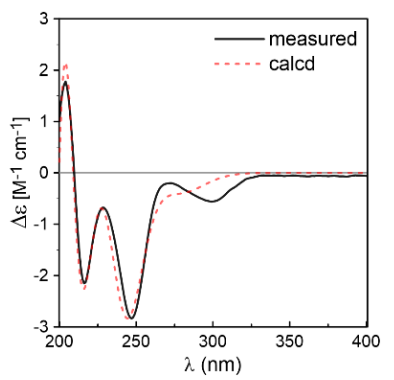

Figure 3. Comparison between the experimental and the CAM-B3LYP/TZVP/PCM (MeOH) calculated ECD spectra of $\mathbf{1}$.

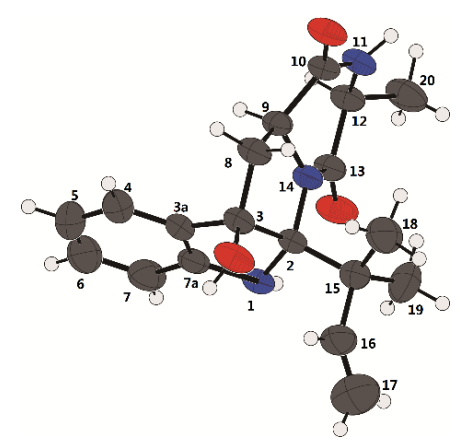

Figure 4. X-ray crystallographic structure of compound 1 (Black: carbon atom; gray: hydrogen atom; red: oxygen atom; blue: nitrogen atom). 
Compound 2 was obtained as white solid. Its molecular formula $\mathrm{C}_{19} \mathrm{H}_{23} \mathrm{~N}_{3} \mathrm{O}_{3}$ was established by positive HRESIMS at $\mathrm{m} / z 342.1813[\mathrm{M}+\mathrm{H}]^{+}$(calcd for 342.1812), which was identical to that of $\mathbf{1}$. The UV, IR, and 1D NMR spectra (Table 1) of $\mathbf{2}$ highly resembled those of $\mathbf{1}$, indicating $\mathbf{2}$ also possessed a hexahydropyrrolo[2,3-b]indole scaffold. Detailed analysis of its 2D NMR (Figure 5) data indicated that $\mathbf{2}$ and $\mathbf{1}$ were represented as a pair of diastereomers. This conclusion could be made by the key HMBC (Figure 5) correlations from H-16 $\left(\delta_{\mathrm{H}} 6.52\right.$, dd, $\left.J=17.6,10.8 \mathrm{~Hz}\right), \mathrm{H}_{3}-18$ $\left(\delta_{\mathrm{H}} 1.36, \mathrm{~s}\right)$, and $\mathrm{H}_{3}-19\left(\delta_{\mathrm{H}} 1.39, \mathrm{~s}\right)$ to $\mathrm{C}-2\left(\delta_{\mathrm{C}} 95.4\right)$, and from $\mathrm{OH}-3\left(\delta_{\mathrm{H}} 4.32, \mathrm{~s}\right)$ to $\mathrm{C}-3\left(\delta_{\mathrm{C}} 88.3\right)$, C-3a $\left(\delta_{\mathrm{C}} 132.7\right)$, and C-8 $\left(\delta_{\mathrm{C}} 36.8\right)$, and NOESY (Figure 5) correlations of $\mathrm{H}_{3}-18$ and $\mathrm{H}_{3}-19$ with $\mathrm{H}-9\left(\delta_{\mathrm{H}} 4.41, \mathrm{dd}, J=10.9,2.5 \mathrm{~Hz}\right), \mathrm{H}-12\left(\delta_{\mathrm{H}} 4.12, \mathrm{q}, J=6.7 \mathrm{~Hz}\right)$, and $\mathrm{OH}-3$, indicating that 2 was a C-2 and C-3 isomer of $\mathbf{1}$. Since 1 was confirmed to be condensed by two L-amino acids, the stereocenters at C-9 and C-12 of 2 tentatively had the same $9 S, 12 S$ configuration as 1 in view of the same biogenetic pathway. Cumulatively, the absolute configuration of $\mathbf{2}$ was assigned as $2 R, 3 S, 9 S, 12 S$. Furthermore, the calculated ECD curve for $2 R, 3 S, 9 S, 12 S-2$ displayed good agreement with the experimental ECD of $\mathbf{2}$ (Figure 6), which confirmed the above elucidation. Thus, the structure of $\mathbf{2}$ was assigned as $2 R, 3 S, 9 S, 12 S$-cyclo-2-dimethylallyl-3-hydroxy-L-Trp-L-Ala (Figure 1) and named eurotiumin B.
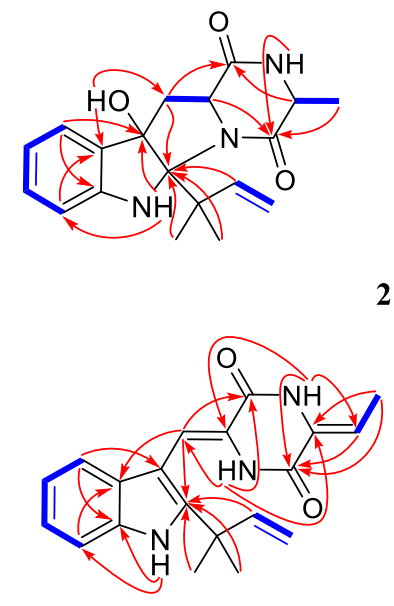

3

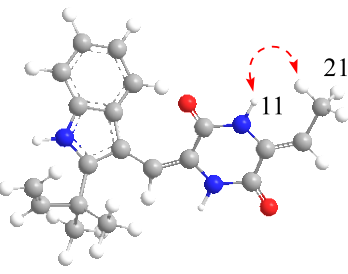

$-{ }^{1} \mathrm{H}-{ }^{1} \mathrm{H} \mathrm{COSY} \curvearrowright \mathrm{HMBC}$

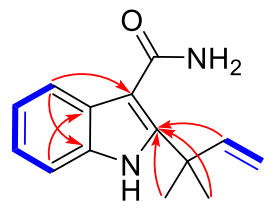

4

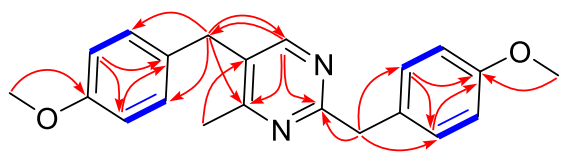

14

Figure 5. Key ${ }^{1} \mathrm{H}_{-}{ }^{1} \mathrm{H}$ COSY, HMBC and NOESY correlations of compounds $\mathbf{2 - 4}$ and $\mathbf{1 4 .}$

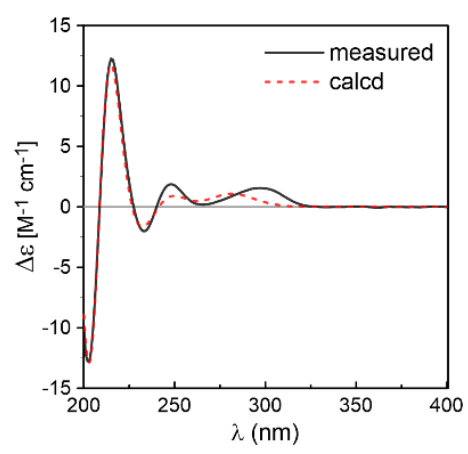

Figure 6. Comparison between the experimental and the CAM-B3LYP/TZVP/PCM (MeOH) calculated ECD spectra of 2 . 
Table 1. ${ }^{1} \mathrm{H}$ and ${ }^{13} \mathrm{C}$ NMR Data for $1-3{ }^{\text {a }}(700,175 \mathrm{MHz}$, TMS, $\delta$ in ppm, $J$ in $\mathrm{Hz})$.

\begin{tabular}{|c|c|c|c|c|c|c|}
\hline \multirow{2}{*}{ Position } & \multicolumn{2}{|r|}{1} & \multicolumn{2}{|r|}{2} & \multicolumn{2}{|r|}{3} \\
\hline & $\delta_{\mathrm{C}}$ & $\delta_{\mathbf{H}}(J, \mathrm{~Hz})$ & $\delta_{\mathrm{C}}$ & $\delta_{\mathrm{H}}(J, \mathrm{~Hz})$ & $\delta_{\mathrm{C}}$ & $\delta_{\mathrm{H}}(J, \mathrm{~Hz})$ \\
\hline 1 & & $6.53 \mathrm{~s}$ & & $6.58 \mathrm{br} \mathrm{s}$ & & $11.12 \mathrm{~s}$ \\
\hline 2 & 92.4 & & 95.4 & & 144.3 & \\
\hline 3 & 89.4 & & 88.3 & & 103.3 & \\
\hline $3 a$ & 132.2 & & 132.7 & & 125.9 & \\
\hline 4 & 124.5 & $7.28 \mathrm{~d}(7.6)$ & 125.5 & $7.17 \mathrm{~d}(7.4)$ & 118.8 & $7.18 \mathrm{~d}(7.9)$ \\
\hline 5 & 120.1 & 6.76 overlap & 119.9 & 6.66 overlap & 119.6 & $7.02 \mathrm{td}(7.5,1.0)$ \\
\hline 6 & 130.8 & $7.12 \mathrm{td}(7.6,1.2)$ & 130.3 & $7.02 \mathrm{td}(7.5,1.3)$ & 120.9 & 7.10 td $(7.6,1.1)$ \\
\hline 7 & 111.8 & 6.75 overlap & 111.3 & 6.64 overlap & 111.7 & $7.43 \mathrm{~d}(8.1)$ \\
\hline $7 a$ & 150.6 & & 149.9 & & 135.1 & \\
\hline 8 & 36.4 & $\begin{array}{c}\text { a } 2.76 \mathrm{dd}(12.7,11.2) \\
\text { b } 2.56 \mathrm{dd}(12.7,7.6)\end{array}$ & 36.8 & $\begin{array}{l}\text { a } 3.35 \mathrm{dd}(13.3,2.3) \\
\text { b } 2.64 \mathrm{dd}(13.4,10.9)\end{array}$ & 110.8 & $6.94 \mathrm{~s}$ \\
\hline 9 & 59.2 & $3.73 \mathrm{dd}(11.2,7.6)$ & 59.4 & $4.41 \mathrm{dd}(10.9,2.5)$ & 124.5 & \\
\hline 10 & 170.6 & & 169.3 & & 157.6 & \\
\hline 11 & & 7.16 br s & & 6.85 br s & & $10.21 \mathrm{~s}$ \\
\hline 12 & 53.0 & $3.91 \mathrm{q}(6.9)$ & 51.0 & $4.11 \mathrm{q}(6.7)$ & 128.4 & \\
\hline 13 & 174.1 & & 170.3 & & 156.4 & \\
\hline 14 & & & & & & $8.68 \mathrm{~s}$ \\
\hline 15 & 45.7 & & 45.8 & & 40.0 & \\
\hline 16 & 146.5 & $6.36 \mathrm{dd}(17.6,10.9)$ & 146.3 & $6.52 \mathrm{dd}(17.6,10.8)$ & 145.1 & $6.08 \mathrm{dd}(17.4,10.5)$ \\
\hline 17 & 111.8 & $4.98 \mathrm{dd}(17.7,1.2)$ & 112.4 & $5.14 \mathrm{dd}(17.7,1.6)$ & 111.7 & $5.06 \mathrm{dd}(10.4,1.2)$ \\
\hline & & $4.90 \mathrm{dd}(10.9,1.5)$ & & $5.02 \mathrm{dd}(10.7,1.6)$ & & $5.03 \mathrm{dd}(17.4,1.2)$ \\
\hline 18 & 24.7 & $1.27 \mathrm{~s}$ & 24.7 & $1.36 \mathrm{~s}$ & 27.5 & $1.48 \mathrm{~s}$ \\
\hline 19 & 25.7 & $1.29 \mathrm{~s}$ & 25.5 & $1.39 \mathrm{~s}$ & 27.5 & $1.48 \mathrm{~s}$ \\
\hline 20 & 15.8 & $1.33 \mathrm{~d}(6.9)$ & 14.9 & $1.15 \mathrm{~d}(6.7)$ & 112.9 & $5.87 \mathrm{q}(7.6)$ \\
\hline 21 & & & & & 11.1 & $1.81 \mathrm{~d}(7.6)$ \\
\hline $3-\mathrm{OH}$ & & $4.49 \mathrm{~s}$ & & $4.32 \mathrm{~s}$ & & \\
\hline
\end{tabular}

Compound 3 was isolated as yellow oil. The molecular formula $\mathrm{C}_{20} \mathrm{H}_{21} \mathrm{~N}_{3} \mathrm{O}_{2}$ was determined on the basis of negative HRESIMS at $m / z 334.1567[\mathrm{M}-\mathrm{H}]^{-}$(calcd for 334.1561), corresponding to an index of hydrogen deficiency of 12. Its IR spectrum suggested the presence of amine groups (3363, $3197 \mathrm{~cm}^{-1}$ ) and carbonyl functionalities $\left(1678,1647 \mathrm{~cm}^{-1}\right)$. Its ${ }^{1} \mathrm{H}$ NMR (Table 1) spectrum recorded in dimethyl sulfoxide- $d_{6}$ showed four aromatic protons at $\delta_{\mathrm{H}} 7.02(\mathrm{td}, J=7.5,1.0 \mathrm{~Hz}), 7.18(\mathrm{~d}, J=7.9 \mathrm{~Hz})$, $7.10(\mathrm{td}, J=7.6,1.1 \mathrm{~Hz})$, and $7.43(\mathrm{~d}, J=8.1 \mathrm{~Hz})$, three NH signals at $\delta_{\mathrm{H}} 8.68(\mathrm{~s}), 10.21(\mathrm{~s})$, and $11.12(\mathrm{~s})$, in combination with four aromatic methines at $\delta_{\mathrm{C}} 111.7,118.8,119.6$, and 120.9 , four quaternary carbons at $\delta_{\mathrm{C}} 103.3,125.9,135.1$, and 144.3 , together with two amides at $\delta_{\mathrm{C}} 156.4$ and 157.6 in the ${ }^{13} \mathrm{C}$ NMR (Table 1) spectrum, suggesting a 2,3-disubstituted indole DKP substructure [3]. Careful comparison of its 1D and 2D NMR (Figure 5) data with neoechinulin B (10) [15] showed high similarities except for that an olefinic methylene $\left(\delta_{\mathrm{H}} 5.02, \mathrm{~s} ; 5.36, \mathrm{~s} ; \delta_{\mathrm{C}} 100.0\right)$ in neoechinulin $\mathrm{B}$ was transformed into an olefinic methine $\left(\delta_{\mathrm{H}} 5.87, \mathrm{q}, J=7.6 \mathrm{~Hz} ; \delta_{\mathrm{C}} 112.9\right)$ substituted by a doublet methyl $\left(\delta_{\mathrm{H}} 1.81, \mathrm{~d}, J=7.6 \mathrm{~Hz}\right.$; $\left.\delta_{\mathrm{C}} 11.1\right)$ in 3 . The above conclusion was verified by the key ${ }^{1} \mathrm{H}-{ }^{1} \mathrm{H}$ correlation spectroscopy $\left({ }^{1} \mathrm{H}-{ }^{1} \mathrm{H}\right.$ COSY) cross peak of $\mathrm{H}-20 / \mathrm{H}_{3}-21$ and $\mathrm{HMBC}$ correlations from NH-11 $\left(\delta_{\mathrm{H}} 10.21, \mathrm{~s}\right)$ to $\mathrm{C}-9\left(\delta_{\mathrm{C}} 124.5\right)$, $\mathrm{C}-12\left(\delta_{\mathrm{C}} 128.4\right)$, and $\mathrm{C}-13\left(\delta_{\mathrm{C}} 156.4\right)$, from $\mathrm{H}-20\left(\delta_{\mathrm{H}} 5.87\right)$ to $\mathrm{C}-13$ and $\mathrm{C}-21\left(\delta_{\mathrm{C}} 11.1\right)$, and from $\mathrm{H}_{3}-21$ $\left(\delta_{\mathrm{H}} 1.81\right)$ to $\mathrm{C}-12, \mathrm{C}-13$ and $\mathrm{C}-20\left(\delta_{\mathrm{C}} 112.9\right)$. The geometry of the $\Delta^{8}$ double bond was elucidated to be $\mathrm{Z}$ configuration by the downfield shift of $\mathrm{H}-8\left(\delta_{\mathrm{H}} 6.94\right.$, s) due to the deshielding effect of the carbonyl group on the $\beta$-vinyl proton, which was also coincident with the lack of NOE effect between $\mathrm{H}-8$ and NH-14 [16]. The newly generated $\Delta^{12}$ double bond in 3 was elucidated as $Z$ geometry by the key NOESY (Figure 5) cross peak of $\mathrm{H}_{3}-21$ with NH-11. Thus the gross structure of 3 was depicted as shown in Figure 1 and named eurotiumin $\mathrm{C}$.

Compound 4 was isolated as yellow solid. The molecular formula $\mathrm{C}_{14} \mathrm{H}_{16} \mathrm{~N}_{2} \mathrm{O}$ was determined on the basis of positive HRESIMS at $m / z 251.1159[\mathrm{M}+\mathrm{Na}]^{+}$(calcd for 251.1155), corresponding to an index of hydrogen deficiency of 8 . Its IR spectrum suggested the presence of amine groups $\left(3312,3273 \mathrm{~cm}^{-1}\right)$ 
and carbonyl functionality $\left(1645 \mathrm{~cm}^{-1}\right)$. Its ${ }^{1} \mathrm{H}$ NMR (Table 2) spectrum recorded in acetone- $d_{6}$ showed two methyls both at $\delta_{\mathrm{H}} 1.64(\mathrm{~s})$, one monosubstituted double bond at $\delta_{\mathrm{H}} 5.06(\mathrm{dd}, J=10.6,1.2 \mathrm{~Hz})$, $5.12(\mathrm{dd}, J=17.5,1.2 \mathrm{~Hz}), 6.41(\mathrm{dd}, J=17.5,10.6 \mathrm{~Hz})$, four aromatic protons at $\delta_{\mathrm{H}} 7.04(\mathrm{td}, J=7.1,1.2 \mathrm{~Hz})$, $7.07(\mathrm{td}, J=7.0,1.3 \mathrm{~Hz}), 7.37(\mathrm{~d}, J=8.1 \mathrm{~Hz})$, and $7.70(\mathrm{~d}, J=7.7 \mathrm{~Hz})$, combined with four aromatic methines at $\delta_{\mathrm{C}} 112.0,120.2,120.8$, and 122.1, four quaternary carbons at $\delta_{\mathrm{C}} 109.8,128.5,135.1$, and 146.1 in the ${ }^{13} \mathrm{C}$ NMR (Table 2) spectrum, implying a prenylated indole alkaloid substructure. Its $1 \mathrm{D}$ and 2D (Figure 5) NMR data highly resembled that of 2-(2-methyl-3-en-2-yl)-1H-indole-3-carbaldehyde, which was isolated from this fungus previously [13]. The only difference was that the aldehyde group at C-3 was replaced by an amide group, which could be deduced by the HRESIMS data and upfield of C-8 chemical shift from $\delta_{\mathrm{C}} 186.6$ in 2-(2-methyl-3-en-2-yl)- $1 H$-indole-3-carbaldehyde to $\delta_{\mathrm{C}} 169.1$ in 4 . Thus, the structure of 4 was assigned as 2-(2-methyl-3-en-2-yl)- $1 H$-indole-3-carboxamide (Figure 1) and named eurotiumin D.

Table 2. ${ }^{1} \mathrm{H}$ and ${ }^{13} \mathrm{C}$ NMR Data for 4 and $14{ }^{\mathrm{a}}(700,175 \mathrm{MHz}, \mathrm{TMS}, \delta$ in ppm, $J$ in $\mathrm{Hz})$.

\begin{tabular}{|c|c|c|c|c|c|}
\hline \multirow{2}{*}{ Position } & \multicolumn{2}{|r|}{4} & \multirow{2}{*}{ Position } & \multicolumn{2}{|c|}{14} \\
\hline & $\delta_{\mathrm{C}}$ & $\delta_{\mathrm{H}}(J, \mathrm{~Hz})$ & & $\delta_{\mathrm{C}}$ & $\delta_{\mathbf{H}}(J, \mathbf{H z})$ \\
\hline 1 & & & 1 & & \\
\hline 2 & 146.1 & & 2 & 152.9 & \\
\hline 3 & 109.8 & & 3 & & \\
\hline $3 a$ & 128.5 & & 4 & 154.4 & \\
\hline 4 & 120.2 & $7.70 \mathrm{~d}(7.7)$ & 5 & 152.2 & \\
\hline 5 & 120.8 & $7.04 \mathrm{td}(7.1,1.2)$ & 6 & 141.5 & $8.26 \mathrm{~s}$ \\
\hline 6 & 122.1 & $7.07 \mathrm{td}(7.0,1.3)$ & 7 & 22.1 & $2.44 \mathrm{~s}$ \\
\hline 7 & 112.0 & $7.37 \mathrm{~d}(8.1)$ & $1^{\prime}$ & 132.2 & \\
\hline $7 a$ & 135.1 & & $2^{\prime} / 6^{\prime}$ & 130.8 & $7.23 \mathrm{~d}(8.7)$ \\
\hline 8 & 169.1 & & $3^{\prime} / 5^{\prime}$ & 114.8 & $6.85 \mathrm{~d}(8.6)$ \\
\hline 9 & 40.0 & & $4^{\prime}$ & 159.3 & \\
\hline 10 & 147.0 & $\begin{array}{c}6.41 \mathrm{dd}(17.5 \\
10.6)\end{array}$ & $7^{\prime}$ & 41.0 & $4.08 \mathrm{~s}$ \\
\hline \multirow[t]{2}{*}{11} & 112.3 & $\begin{array}{c}5.12 \mathrm{dd}(17.5 \\
1.2)\end{array}$ & $4^{\prime}$-OMe & 55.4 & $3.75 \mathrm{~s}$ \\
\hline & & $\begin{array}{c}5.06 \mathrm{dd}(10.6 \\
1.2)\end{array}$ & $1^{\prime \prime}$ & 131.3 & \\
\hline 12 & 27.3 & $1.64 \mathrm{~s}$ & $2^{\prime \prime} / 6^{\prime \prime}$ & 130.5 & $7.12 \mathrm{~d}(8.7)$ \\
\hline \multirow[t]{4}{*}{13} & 27.3 & $1.64 \mathrm{~s}$ & $3^{\prime \prime} / 5^{\prime \prime}$ & 114.7 & $6.82 \mathrm{~d}(8.7)$ \\
\hline & & & $4^{\prime \prime}$ & 159.3 & \\
\hline & & & $7^{\prime \prime}$ & 40.7 & $4.01 \mathrm{~s}$ \\
\hline & & & $4^{\prime \prime}-\mathrm{OMe}$ & 55.4 & $3.73 \mathrm{~s}$ \\
\hline
\end{tabular}

a 4 and 14 in acetone- $d_{6}$.

Compound 14 was isolated as yellow solid. Its positive HRESIMS at $m / z 335.1764[\mathrm{M}+\mathrm{H}]^{+}(\mathrm{calcd}$ for 335.1754) revealed a molecular formula of $\mathrm{C}_{21} \mathrm{H}_{22} \mathrm{~N}_{2} \mathrm{O}_{2}$ with an index of hydrogen deficiency of 12 . Its ${ }^{1} \mathrm{H}$ NMR (Table 2) spectrum recorded in acetone- $d_{6}$ showed one methyl at $\delta_{\mathrm{H}} 2.44(\mathrm{~s})$, two methoxyls at $\delta_{\mathrm{H}} 3.73(\mathrm{~s}), 3.75(\mathrm{~s})$, two aliphatic methylenes at $\delta_{\mathrm{H}} 4.01(\mathrm{~s}), 4.08(\mathrm{~s})$, nine aromatic protons at $\delta_{\mathrm{H}} 6.82$ $(\mathrm{d}, J=8.6 \mathrm{~Hz}), 6.85(\mathrm{~d}, J=8.6 \mathrm{~Hz}), 7.12(\mathrm{~d}, J=8.7 \mathrm{~Hz}), 7.23(\mathrm{~d}, J=8.7 \mathrm{~Hz})$, and $8.26(\mathrm{~s})$. The ${ }^{13} \mathrm{C} \mathrm{NMR}$ and DEPT revealed 21 carbon resonances, including one methyl, two methoxyls, two methylenes, nine methines, and seven quaternary carbons. Carefully analysis of its 1D (Table 2) and 2D NMR (Figure 5) data showed two 4-methoxybenzyl moieties and one 4-methylpyrimidine unit. The two 4-methoxybenzyl moieties could be judged by the ${ }^{1} \mathrm{H}$ NMR resonances of two $\mathrm{AA}^{\prime} \mathrm{BB}^{\prime}$ patterns for protons at $\mathrm{H}-2^{\prime} / \mathrm{H}-6^{\prime}\left(\delta_{\mathrm{H}} 7.23, \mathrm{~d}, J=8.7 \mathrm{~Hz}\right), \mathrm{H}-3^{\prime} / \mathrm{H}-5^{\prime}\left(\delta_{\mathrm{H}} 6.85, \mathrm{~d}, J=8.6 \mathrm{~Hz}\right), \mathrm{H}-2^{\prime \prime} / \mathrm{H}-6^{\prime \prime}\left(\delta_{\mathrm{H}} 7.12\right.$, $\mathrm{d}, J=8.7 \mathrm{~Hz})$, and $\mathrm{H}-3^{\prime \prime} / \mathrm{H}-5^{\prime \prime}\left(\delta_{\mathrm{H}} 6.82, \mathrm{~d}, J=8.7 \mathrm{~Hz}\right)$, and ${ }^{1} \mathrm{H}^{1}{ }^{1} \mathrm{H}$ COSY correlations of $\mathrm{H}-2^{\prime} / \mathrm{H}-3^{\prime}$, $\mathrm{H}-5^{\prime} / \mathrm{H}-6^{\prime}, \mathrm{H}-2^{\prime \prime} / \mathrm{H}-3^{\prime \prime}, \mathrm{H}-5^{\prime \prime} / \mathrm{H}-6^{\prime \prime}$, and HMBC correlations from H-7' $\left(\delta_{\mathrm{H}} 4.08, \mathrm{~s}\right)$ to $\mathrm{C}-1^{\prime}\left(\delta_{\mathrm{C}} 132.2\right)$, $\mathrm{C}-2^{\prime} / \mathrm{C}-6^{\prime}\left(\delta_{\mathrm{C}} 130.8\right)$, from $\mathrm{H}-7^{\prime \prime}\left(\delta_{\mathrm{H}} 4.01\right.$, s) to C-1" $\left(\delta_{\mathrm{C}} 131.3\right), \mathrm{C}-2^{\prime \prime} / \mathrm{C}-6^{\prime \prime}\left(\delta_{\mathrm{C}} 130.5\right)$, from $4^{\prime}-\mathrm{OMe}$ $\left(\delta_{\mathrm{H}} 3.75, \mathrm{~s}\right)$ to $\mathrm{C}-4^{\prime}\left(\delta_{\mathrm{C}} 159.3\right)$, and from $4^{\prime \prime}-\mathrm{OMe}\left(\delta_{\mathrm{H}} 3.73, \mathrm{~s}\right)$ to $\mathrm{C}-4^{\prime \prime}\left(\delta_{\mathrm{C}} 159.3\right)$. The 4-methylpyrimidine 
part could be elucidated by the HRESIMS data and HMBC correlations from H-6 $\left(\delta_{\mathrm{H}} 8.26\right.$, s) to $\mathrm{C}-2\left(\delta_{\mathrm{C}} 152.9\right), \mathrm{C}-4\left(\delta_{\mathrm{C}} 154.4\right), \mathrm{C}-7^{\prime \prime}\left(\delta_{\mathrm{C}} 40.7\right)$, and from $\mathrm{H}_{3}-7\left(\delta_{\mathrm{H}} 2.44, \mathrm{~s}\right)$ to $\mathrm{C}-5\left(\delta_{\mathrm{C}} 152.2\right)$. The two 4-methoxybenzyl moieties were located at $\mathrm{C}-2$ and $\mathrm{C}-5$ of 4-methylpyrimidine, respectively, which was evidenced by the HMBC correlations from $\mathrm{H}-7^{\prime}$ to $\mathrm{C}-2$, from $\mathrm{H}-7^{\prime \prime}$ to $\mathrm{C}-4, \mathrm{C}-6$. Thus, the structure of 14 was established as 2,5-bis(4-methoxybenzyl)-4-methylpyrimidine (Figure 1) and named eurotiumin E. Benzyl pyrimidines are prominent heterocyclic compounds with significant pharmaceutical activities, such as inhibiting HIV-1 reverse transcriptase [17], binding specifically to human serum albumin and determining the drug distribution [18], and acting against bacterial and avian dihydrofolate reductase [19]. To the best of our knowledge, benzyl pyrimidines were reported mainly as chemical synthetic products $[17,20,21]$, but rarely as natural products. This investigation could shed light on the further discovery of benzyl pyrimidines from marine fungi.

In addition to the isolation of the above new compounds 1-4 and 14, nine known DKPs including dehydroechinulin (5) [22], variecolorin G (6) [5], isoechinulin A (7) [5], dehydrovariecolorin L (8) [22], variecolorin O (9) [23], neoechinulin B (10) [15], variecolorin J (11) [5], echinulin (12) [22], and cyclo-(L-Pro-L-Phe) (13) [24] were also isolated and identified from this fungus. Their structures (Figure 1) were elucidated by comparison of their NMR and MS data with reported literature.

Prenylated DKP alkaloids had been reported exhibiting antioxidative and cytotoxic activities [1-3,6], thus all the compounds except $\mathbf{8}$ and 11, due to the sample quantity limitation, were screened for antioxidative activities against DPPH [25] (Table 3). Compounds 3, 5, 6, 7, 9, 10, and 12 showed significant radical scavenging activities against DPPH with $\mathrm{IC}_{50}$ values of $13,19,4,3,24,13$, and $18 \mu \mathrm{M}$, respectively, which were comparable to that of the positive control ascorbic acid (Vc) $(23 \mu \mathrm{M})$. Compounds 1, 2, and 13 exhibited moderate antioxidative activities with $\mathrm{IC}_{50}$ values ranging from 35 to $69 \mu \mathrm{M}$. Based on the antioxidative activities results, diprenylated analogs (6 and 7) seemed to be more active than monoprenylated ones (1-3, 9, and 10), and triprenylated ones (5 and 12). Particularly, as for $\mathbf{1}$ and 2, the absolute configurations of the C-2 and C-3 appeared to have influence on the antioxidative activities. The new compounds $\mathbf{1 - 4}$, and $\mathbf{1 4}$ were evaluated for their cytotoxic activities against SF-268 and HepG2 cell lines in vitro with the SRB method [26]. The results showed that none of them exhibited obvious cytotoxicity against these two cancer cell lines $\left(\mathrm{IC}_{50}>100 \mu \mathrm{M}\right)$.

Table 3. Antioxidative activities of compounds $\mathbf{1 - 7}, \mathbf{9 - 1 0}$, and $\mathbf{1 2 - 1 4}\left(\mathrm{IC}_{50}, \mu \mathrm{M}\right)$.

\begin{tabular}{cccccccccccccc}
\hline Nos. & $\mathbf{1}$ & $\mathbf{2}$ & $\mathbf{3}$ & $\mathbf{4}$ & $\mathbf{5}$ & $\mathbf{6}$ & $\mathbf{7}$ & $\mathbf{9}$ & $\mathbf{1 0}$ & $\mathbf{1 2}$ & $\mathbf{1 3}$ & $\mathbf{1 4}$ & $\mathrm{V}_{\mathrm{C}}$ \\
\hline $\mathrm{IC}_{50}$ & 37 & 69 & 13 & $>100$ & 19 & 4 & 3 & 24 & 13 & 18 & 35 & $>100$ & 23 \\
\hline
\end{tabular}

\section{Materials and Methods}

\subsection{General Experimental Procedures}

Optical rotations were measured with an MCP 500 automatic polarimeter (Anton Paar, Graz, Austria) with MeCN as solvent. UV spectra were recorded on a UV-2600 spectrometer (Shimadzu, Tokyo, Japan). IR spectra were measured on an IR Affinity-1 spectrometer (Shimadzu). ${ }^{1} \mathrm{H},{ }^{13} \mathrm{C}$ NMR, DEPT and 2D NMR spectra were recorded on the AVANCE III HD 700 (Bruker, Billerica, MA, USA). Circular dichroism spectra were measured with a Chirascan circular dichroism spectrometer (Applied Photophysics, Surrey, UK). HRESIMS spectra data were recorded on a MaXis quadrupole-time-of-flight mass spectrometer. Crystallographic data was collected on a Rigaku XtaLAB AFC12 single-crystal diffractometer using $\mathrm{Cu} K \alpha$ radiation. Thin layer chromatography (TLC) was performed on plates precoated with silica gel $\mathrm{GF}_{254}(10-40 \mu \mathrm{m})$. Column chromatography $(\mathrm{CC})$ was performed over silica gel (200-300 mesh and 300-400 mesh) (Qingdao Marine Chemical Factory, Qingdao, China) and ODS (50 $\mu \mathrm{m}, \mathrm{YMC}$, Kyoto, Japan). High performance liquid chromatography was performed on an Agilent 1260 HPLC equipped with a DAD detector, using an ODS column (YMC-pack ODS-A, $10 \times 250 \mathrm{~mm}, 5 \mu \mathrm{m}, 3 \mathrm{~mL} / \mathrm{min}$ ). All solvents used in CC and HPLC were of analytical grade (Tianjin 
Damao Chemical Plant, Tianjin, China) and chromatographic grade (Oceanpak, Goteborg, Sweden), respectively. Fractions were monitored by TLC and spots were visualized by heating silica gel plates sprayed with $10 \% \mathrm{H}_{2} \mathrm{SO}_{4}$ in $\mathrm{EtOH}$.

\subsection{Fungal Material}

The fungal strain used in this investigation was isolated from a South China Sea sediment sample $\left(17^{\circ} 29.804^{\prime} \mathrm{N}, 110^{\circ} 0.292^{\prime} \mathrm{E}\right)$ at a depth of $158 \mathrm{~m}$ in May 2010. It was identified as Eurotium sp. SCSIO F452, according to a molecular biological protocol by DNA amplification and sequencing of the ITS region (deposited in GenBank, accession no. JX481973). The working strain was prepared on potato dextrose agar slants modified with seawater instead of distilled water and stored at $4{ }^{\circ} \mathrm{C}$. A reference culture was maintained at $-80^{\circ} \mathrm{C}$ in RNAM Center for Marine Microbiology, South China Sea Institute of Oceanology, Chinese Academy of Sciences.

\subsection{Fermentation, Extraction, and Isolation}

The strain Eurotium sp. SCSIO F452 was cultured under static conditions at $28^{\circ} \mathrm{C}$ in $500 \mathrm{~mL} \times 200$ conical flasks containing the liquid medium $(150 \mathrm{~mL} /$ flask $)$ composed of maltose $(20 \mathrm{~g} / \mathrm{L})$, glucose $(10 \mathrm{~g} / \mathrm{L})$, mannitol $(20 \mathrm{~g} / \mathrm{L})$, corn syrup $(1 \mathrm{~g} / \mathrm{L})$, sodium glutamate $(10 \mathrm{~g} / \mathrm{L})$, yeast extract $(3 \mathrm{~g} / \mathrm{L})$, $\mathrm{KH}_{2} \mathrm{PO}_{4}(0.5 \mathrm{~g} / \mathrm{L}), \mathrm{MgSO}_{4} \cdot 7 \mathrm{H}_{2} \mathrm{O}(0.3 \mathrm{~g} / \mathrm{L}), \mathrm{CaCO}_{3}(2 \mathrm{~g} / \mathrm{L})$, sea salt $(30 \mathrm{~g} / \mathrm{L})$ (adjusted $\mathrm{pH}$ to 6.5 before sterilization). The fermented whole broth $(30 \mathrm{~L})$ was filtered through cheesecloth to separate into filtrate and mycelia. The filtrate was concentrated under vacuum to about a quarter of the original volume and then extracted three times with EtOAc, while the mycelia were extracted three times with $80 \%$ Acetone $/ \mathrm{H}_{2} \mathrm{O}$. The acetone solution was evaporated under reduced pressure to afford an aqueous solution. The aqueous solution was extracted three times with EtOAc to give another EtOAc solution. Both EtOAc solutions were combined and concentrated under reduced pressure to give the whole crude extract (68 g).

\subsection{Purification}

The EtOAc extract (68 g) was subjected to vacuum liquid chromatography (VLC) on a silica gel column using step gradient elution with petroleum ether (PE)/EtOAc (1:0 to 0:1) and $\mathrm{CHCl}_{3} / \mathrm{MeOH}$ (1:0 to 0:1) to separate into eighteen fractions based on TLC properties. Fr.4 (13 g) was separated by silica gel CC (PE/Acetone 1:0 to 0:1) to obtain nine subfractions (Frs.4.1-4.9). Then Fr.4.7 (0.9 g) was divided into ten parts (Frs.4.7.1-4.7.10) by ODS CC with a gradient elution of $\mathrm{MeOH} / \mathrm{H}_{2} \mathrm{O}$ (7:3 to 1:0). Fr.4.7.1 (156 mg) was further purified by $\mathrm{HPLC}\left(55 \% \mathrm{CH}_{3} \mathrm{OH} / \mathrm{H}_{2} \mathrm{O}\right)$ to yield $\mathbf{1}(3.5 \mathrm{mg})$, $2(2.0 \mathrm{mg}), 4(4.1 \mathrm{mg})$. Fr.4.7.2 $(116 \mathrm{mg})$ was purified by $\mathrm{HPLC}\left(73 \% \mathrm{CH}_{3} \mathrm{CN} / \mathrm{H}_{2} \mathrm{O}\right)$ to yield $\mathbf{5}(1.0 \mathrm{mg})$, $10(9.5 \mathrm{mg}), \mathbf{1 3}(24.5 \mathrm{mg})$. Fr.4.7.3 $(22 \mathrm{mg})$ was purified by $\mathrm{HPLC}\left(72 \% \mathrm{CH}_{3} \mathrm{CN} / \mathrm{H}_{2} \mathrm{O}\right)$ to yield 6 (3.1 mg). Fr.4.6 (322 mg) was purified by repeated HPLC $\left(65 \% \mathrm{CH}_{3} \mathrm{OH} / \mathrm{H}_{2} \mathrm{O}\right)$ to yield $7(7.0 \mathrm{mg})$, $11(0.8 \mathrm{mg}), \mathbf{1 2}(48.2 \mathrm{mg})$. Fr.3 (9.2 g) was separated by silica gel CC (PE/Acetone 1:0 to 0:1) to obtain ten subfractions (Frs.3.1-3.10). Then Fr.3.8 (162 mg) was further purified by HPLC $\left(51 \% \mathrm{CH}_{3} \mathrm{CN} / \mathrm{H}_{2} \mathrm{O}\right)$ to yield $3(1.5 \mathrm{mg}), 8(0.7 \mathrm{mg})$. Fr.3.9 $(162 \mathrm{mg})$ was purified by HPLC $\left(45 \% \mathrm{CH}_{3} \mathrm{CN} / \mathrm{H}_{2} \mathrm{O}\right)$ to yield $\mathbf{9}(5.1 \mathrm{mg}), \mathbf{1 4}(1.1 \mathrm{mg})$.

\subsection{Spectral Data}

Eurotiumin A (1): white crystals; $[\alpha]_{D}^{25}=-120.9\left(\mathrm{c} 0.1, \mathrm{CH}_{3} \mathrm{CN}\right) ; \mathrm{UV}\left(\mathrm{CH}_{3} \mathrm{CN}\right) \lambda_{\max }(\log \varepsilon) 205$ (4.02), 241 (3.54), 295 (3.02) nm; IR (film) $v_{\max } 3366,3312,2926,1684,1668,1364,1151,750 \mathrm{~cm}^{-1}$; HRESIMS at $\mathrm{m} / \mathrm{z} 342.1816[\mathrm{M}+\mathrm{H}]^{+}$(calcd for 342.1812). ${ }^{1} \mathrm{H}$ and ${ }^{13} \mathrm{C}$ NMR see Table 1.

Eurotiumin B (2): white solid; $[\alpha]_{D}^{25}=+76.5\left(\mathrm{c} 0.067, \mathrm{CH}_{3} \mathrm{CN}\right)$; $\mathrm{UV}\left(\mathrm{CH}_{3} \mathrm{CN}\right) \lambda_{\max }(\log \varepsilon) 204$ (4.41), 237 (3.96), 296 (3.24) nm; IR (film) $v_{\max }$ 3366, 3273, 2924, 1683, 1653, 1472, 1379,1092, $750 \mathrm{~cm}^{-1}$; HRESIMS at $m / z 342.1813[\mathrm{M}+\mathrm{H}]^{+}$(calcd for 342.1812$) .{ }^{1} \mathrm{H}$ and ${ }^{13} \mathrm{C}$ NMR see Table 1. 
Eurotiumin C (3): yellow oil; $[\alpha]_{D}^{25}=+2.8\left(\mathrm{c} 0.01, \mathrm{CH}_{3} \mathrm{CN}\right)$; UV $\left(\mathrm{CH}_{3} \mathrm{CN}\right) \lambda_{\max }(\log \varepsilon) 226$ (4.23), 272 (4.03), 353 (3.86) nm; IR (film) $v_{\max } 3364,3292,2924,1678,1647,1396,1371,744 \mathrm{~cm}^{-1}$; HRESIMS at $\mathrm{m} / \mathrm{z} 334.1567[\mathrm{M}-\mathrm{H}]^{-}$(calcd for 334.1561). ${ }^{1} \mathrm{H}$ and ${ }^{13} \mathrm{C}$ NMR see Table 1.

Eurotiumin D (4): yellow solid; $[\alpha]_{D}^{25}=-2.7\left(\mathrm{c} 0.1, \mathrm{CH}_{3} \mathrm{CN}\right)$; $\mathrm{UV}\left(\mathrm{CH}_{3} \mathrm{CN}\right) \lambda_{\max }(\log \varepsilon) 219$ (4.05), 281 (3.40), 288 (3.35) nm; IR (film) $v_{\max } 3312,3273,2967,1645,1637,1225,746 \mathrm{~cm}^{-1}$; HRESIMS at $\mathrm{m} / \mathrm{z}$ $251.1159[\mathrm{M}+\mathrm{Na}]^{+}$(calcd for 251.1155). ${ }^{1} \mathrm{H}$ and ${ }^{13} \mathrm{C}$ NMR see Table 2.

Eurotiumin E (14): yellow solid; $[\alpha]_{D}^{25}=+5.1$ (c $\left.0.1, \mathrm{CH}_{3} \mathrm{CN}\right) ; \mathrm{UV}\left(\mathrm{CH}_{3} \mathrm{CN}\right) \lambda_{\max }(\log \varepsilon) 208(4.40)$, 226 (4.37), 280 (4.20) nm; HRESIMS at $m / z 335.1764[\mathrm{M}+\mathrm{H}]^{+}$(calcd for 335.1754). ${ }^{1} \mathrm{H}$ and ${ }^{13} \mathrm{C}$ NMR see Table 2.

\subsection{Computational Methods}

Molecular Merck force field (MMFF) calculations were done using Spartan'14 program (Wavefunction Inc., Irvine, CA, USA). Density functional theory (DFT) and time-dependent density functional theory (TDDFT) calculations were performed with Gaussian09 program package [27]. For conformational analysis, the conformers generated by a MMFF conformational search in an energy window of $10 \mathrm{kcal} / \mathrm{mol}$ were subjected to geometry optimization using the DFT method at the B3LYP/def2-SVP level. Frequency calculations were run at the same level to estimate their relative thermal $(\Delta E)$ and free energies $(\Delta G)$ at $298.15 \mathrm{~K}$. Energies of the low-energy conformers were re-calculated at the M06-2X/def2-TZVP level. Solvent $(\mathrm{MeOH})$ effects were taken into account by using polarizable continuum model (IEFPCM). The TDDFT calculations were performed using the hybrid PBE1PBE, CAM-B3LYP, and M06-2X functionals, and the Ahlrichs' basis sets TZVP [28]. The number of excited states was 36 for both compounds. The ECD spectra were generated by the program SpecDis [29] using a Gaussian band shape from dipole-length dipolar and rotational strengths. The equilibrium population of each conformer at $298.15 \mathrm{~K}$ was calculated from its $\Delta G$ using Boltzmann statistics. The calculated spectra of compounds were generated from the low-energy conformers according to the Boltzmann weighting of each conformer in $\mathrm{MeOH}$ solution.

\subsection{X-ray Crystal Structure Analysis}

Crystallographic data for compound eurotiumin A (1) was collected on a Rigaku XtaLAB AFC12 single-crystal diffractometer using $\mathrm{Cu} \mathrm{K} \alpha$ radiation. The structure of $\mathbf{1}$ was solved by direct methods (SHELXS97), expanded using difference Fourier techniques, and refined by full-matrix least-squares calculation. The non-hydrogen atoms were refined anisotropically, and hydrogen atoms were fixed at calculated positions. Crystallographic data for the structure of eurotiumin A (1) had been deposited in the Cambridge Crystallographic Data Centre database (deposition number CCDC 1829910). Copies of the data could be obtained free of charge from the CCDC at www.ccdc.cam.ac.uk.

Crystal data for 1: $\mathrm{C}_{19} \mathrm{H}_{23} \mathrm{~N}_{3} \mathrm{O}_{3}, \mathrm{M}=341.40$, tetragonal, space group P41, $a=7.91520(10) \AA$, $b=7.91520(10) \AA, c=28.2961(5) \AA, V=1772.76(5) \AA^{3}, a=90^{\circ}, b=90^{\circ}, g=90^{\circ}, Z=4, T=299.8(2) \mathrm{K}$, $\mu(\mathrm{Cu} \mathrm{K} \alpha)=0.712 \mathrm{~mm}^{-1}, D_{\text {calc }}=1.279 \mathrm{~g} / \mathrm{cm}^{3}, 9129$ reflections measured $\left(11.178^{\circ} \leq 2 \Theta \leq 147.856^{\circ}\right)$, 3483 unique $\left(R_{\text {int }}=0.0191, R_{\text {sigma }}=0.0215\right)$, which were used in all calculations. The final $R_{1}$ was 0.0422 $(I>2 \sigma(I))$ and $w R_{2}$ was 0.1256 (all data). The goodness of fit on $F^{2}$ was 1.066. Flack parameter $=0.04(6)$.

\subsection{Antioxidative Assay}

In the radical-scavenging assay, $200 \mu \mathrm{L}$ of reaction mixture containing test sample and $200 \mu \mathrm{M}$ of 1,1-diphenyl-2-picrylhydrazyl (DPPH), dissolved in EtOH, was plated in 96-well plates and incubated at $37^{\circ} \mathrm{C}$ in the dark for $30 \mathrm{~min}$ [25]. After the reaction, the UV/VIS absorbance was measured at $517 \mathrm{~nm}$, and the percent inhibition was calculated. $\mathrm{IC}_{50}$ values denoted the concentration of sample required to scavenge $50 \%$ of the DPPH free radicals. 


\subsection{Cytotoxic Assay}

New compounds 1-4 and $\mathbf{1 4}$ were evaluated for their cytotoxic activities against SF-268 and HepG2 cell lines with the SRB method [20]. Cells $(180 \mu \mathrm{L})$ with a density of $3 \times 10^{4}$ cells $/ \mathrm{mL}$ of media were seeded onto 96 -well plates and incubated for $24 \mathrm{~h}$ at $37^{\circ} \mathrm{C}, 5 \% \mathrm{CO}_{2}$. Twenty $\mu \mathrm{L}$ of various concentrations of compounds were added into each plate well. The plates were further incubated for $72 \mathrm{~h}$. After incubation, cell monolayers were fixed with $50 \%(w / v)$ trichloroacetic acid $(50 \mu \mathrm{L})$ and stained for 30 min with $0.4 \%(w / v)$ SRB dissolved in $1 \%$ acetic acid. Unbound dye was removed by washing repeatedly with $1 \%$ acetic acid. The protein-bound dye was dissolved in $10 \mathrm{mM}$ Tris base solution $(200 \mu \mathrm{L})$ for OD determination at $570 \mathrm{~nm}$ using a microplate reader. Taxol was used as a positive control possessing potent cytotoxic activity. All data were obtained in triplicate and presented as means $\pm \mathrm{SD}$. $\mathrm{IC}_{50}$ values were calculated with the Sigma Plot 10.0 software using a non-linear curve-fitting method.

\section{Conclusions}

Chemical investigation of a marine-derived fungus Eurotium sp. SCSIO F452 led to isolation and identification of three new prenylated indole 2,5-diketopiperazine alkaloids (1-3) with nine known ones (5-13), one new prenylated indole alkaloid (4), and one new bis-benzyl pyrimidine derivative (14). $\mathbf{1}$ and $\mathbf{2}$ both shared a hexahydropyrrolo[2,3-b]indole skeleton, and occurred as a pair of diastereomers. The absolute configuration of $\mathbf{1}$ was determined by quantum chemical calculations of ECD and single crystal X-ray diffraction experiment. $\mathbf{1 4}$ was presented as a 2,5-bis-benzyl pyrimidine derivative rarely from marine-derived fungus. Multiple prenylated DKPs implied the existence of prenyltransferase in this fungus [30,31]. In addition, compounds 3, 5, 6, 7, 9, 10, and 12 showed significant radical scavenging activities against DPPH with $\mathrm{IC}_{50}$ values of $13,19,4,3,24,13$, and $18 \mu \mathrm{M}$, respectively.

Supplementary Materials: The following are available online at http://www.mdpi.com/1660-3397/16/4/136/s1. This section includes 1D, 2D NMR spectra and other spectroscopic data for new compounds 1-4 and 14, and computational details of compounds 1 and 2.

Acknowledgments: This work was financially supported by the National Natural Science Foundation of China (Nos. 41476136, 41776169, 41230962), the National Key Research and Development Program of China (2017YFC0506300), Guangdong Province Science and Technology Plan Project (2015B090904003), and Pearl River S\&T Nova Program of Guangzhou (No. 201710010136). We gratefully acknowledge support from the Guangzhou Branch of the Supercomputing Center of Chinese Academy of Sciences and the analytical facilities in SCSIO.

Author Contributions: Wei-Mao Zhong performed the isolation, purification, characterization, and evaluation the antioxidative activities of all the compounds and prepared the manuscript; Jun-Feng Wang and Xue-Feng Shi contributed to the structure elucidation and revised the manuscript; Xiao-Yi Wei performed the ECD calculations; Yu-Chan Chen and Wei-Min Zhang contributed to the determination of cytotoxic activities; Qi Zeng, Yao Xiang, and Xia-Yu Chen contributed to the isolation of the compounds and determination of antioxidative activities; Xin-Peng Tian contributed to the isolation, purification, and identification of the fungal strain; Zhi-Hui Xiao performed the 1D and 2D NMR experiments; Fa-Zuo Wang and Si Zhang designed and supervised the research and revised the manuscript.

Conflicts of Interest: The authors declare no conflict of interest.

\section{References}

1. Li, S.M. Prenylated indole derivatives from fungi: Structure diversity, biological activities, biosynthesis and chemoenzymatic synthesis. Nat. Prod. Rep. 2010, 27, 57-78. [CrossRef] [PubMed]

2. Ma, Y.M.; Liang, X.A.; Kong, Y.; Jia, B. Structural diversity and biological activities of indole diketopiperazine alkaloids from fungi. J. Agric. Food Chem. 2016, 64, 6659-6671. [CrossRef] [PubMed]

3. Du, F.Y.; Li, X.; Li, X.M.; Zhu, L.W.; Wang, B.G. Indolediketopiperazine alkaloids from Eurotium cristatum EN-220, an endophytic fungus isolated from the marine alga Sargassum thunbergii. Mar. Drugs 2017, 15, 1-10. [CrossRef] [PubMed]

4. Meng, L.H.; Du, F.Y.; Li, X.M.; Pedpradab, P.; Xu, G.M.; Wang, B.G. Rubrumazines A-C, indolediketopiperazines of the isoechinulin class from Eurotium rubrum MA-150, a fungus obtained from marine mangrove-derived rhizospheric soil. J. Nat. Prod. 2015, 78, 909-913. [CrossRef] [PubMed] 
5. Wang, W.L.; Lu, Z.Y.; Tao, H.W.; Zhu, T.J.; Fang, Y.C.; Gu, Q.Q.; Zhu, W.M. Isoechinulin-type alkaloids, variecolorins A-L, from halotolerant Aspergillus variecolor. J. Nat. Prod. 2007, 70, 1558-1564. [CrossRef] [PubMed]

6. Tsukamoto, S.; Kato, H.; Samizo, M.; Nojiri, Y.; Onuki, H.; Hirota, H.; Ohta, T. Notoamides F-K, prenylated indole alkaloids isolated from a marine-derived Aspergillus sp. J. Nat. Prod. 2008, 71, 2064-2067. [CrossRef] [PubMed]

7. Ravikanth, V.; Niranjan Reddy, V.L.; Ramesh, P.; Prabhakar Rao, T.; Diwan, P.V.; Khar, A.; Venkateswarlu, Y. An immunosuppressive tryptophan-derived alkaloid from Lepidagathis cristata. Phytochemistry 2001, 58, 1263-1266. [CrossRef]

8. Fan, Z.; Sun, Z.H.; Liu, Z.; Chen, Y.C.; Liu, H.X.; Li, H.H.; Zhang, W.M. Dichotocejpins A-C: New diketopiperazines from a deep-sea-derived fungus Dichotomomyces cejpii FS110. Mar. Drugs 2016, 14, 1-9. [CrossRef] [PubMed]

9. Wang, J.F.; He, W.J.; Qin, X.C.; Wei, X.Y.; Tian, X.P.; Liao, L.; Liao, S.R.; Yang, B.; Tu, Z.C.; Chen, B.; et al. Three new indolyl diketopiperazine metabolites from the antarctic soil-derived fungus Penicillium sp. SCSIO 05705. RSC Adv. 2015, 5, 68736-68742. [CrossRef]

10. Tian, Z.H.; Chu, Y.Y.; Wang, H.; Zhong, L.L.; Deng, M.Y.; Li, W.B. Biological activity and interaction mechanism of the diketopiperazine derivatives as tubulin polymerization inhibitors. RSC Adv. 2018, 8, 1055-1064. [CrossRef]

11. Wang, F.Z.; Huang, Z.; Shi, X.F.; Chen, Y.C.; Zhang, W.M.; Tian, X.P.; Li, J.; Zhang, S. Cytotoxic indole diketopiperazines from the deep sea-derived fungus Acrostalagmus luteoalbus SCSIO F457. Bioorg. Med. Chem. Lett. 2012, 22, 7265-7267. [CrossRef] [PubMed]

12. Huang, H.B.; Wang, F.Z.; Luo, M.H.; Chen, Y.C.; Song, Y.X.; Zhang, W.M.; Zhang, S.; Ju, J.H. Halogenated anthraquinones from the marine-derived fungus Aspergillus sp. SCSIO F063. J. Nat. Prod. 2012, 75, 1346-1352. [CrossRef] [PubMed]

13. Wang, F.Z.; Huang, Z.; Shi, X.F.; Chen, Y.C.; Zhang, W.M.; Tian, X.P.; Li, J.; Zhang, S. Analysis of secondary metabolites produced by Eurotium sp. SCSIO F452 isolated from the South China Sea sediment. Zhongguo Haiyang Yaowu 2013, 32, 7-12.

14. Wollinsky, B.; Ludwig, L.; Xie, X.; Li, S.M. Breaking the regioselectivity of indole prenyltransferases: Identification of regular C3-prenylated hexahydropyrrolo[2,3- $b$ ]indoles as side products of the regular C2-prenyltransferase FtmPT1. Org. Biomol. Chem. 2012, 10, 9262-9270. [CrossRef] [PubMed]

15. Kim, K.S.; Cui, X.; Lee, D.S.; Sohn, J.H.; Yim, J.H.; Kim, Y.C.; Oh, H. Anti-inflammatory effect of neoechinulin A from the marine fungus Eurotium sp. SF-5989 through the suppression of NF-small ka, CyrillicB and p38 MAPK pathways in lipopolysaccharide-stimulated RAW264.7 macrophages. Molecules 2013, 18, 13245-13259. [CrossRef] [PubMed]

16. Gao, H.Q.; Liu, W.Z.; Zhu, T.J.; Mo, X.; Mandi, A.; Kurtan, T.; Li, J.; Ai, J.; Gu, Q.Q.; Li, D.H. Diketopiperazine alkaloids from a mangrove rhizosphere soil derived fungus Aspergillus effuses H1-1. Org. Biomol. Chem. 2012, 10, 9501-9506. [CrossRef] [PubMed]

17. Mai, A.; Artico, M.; Sbardella, G.; Massa, S.; Novellino, E.; Greco, G.; Loi, A.G.; Tramontano, E.; Marongiu, M.E.; La Colla, P. 5-Alkyl-2-(alkylthio)-6-(2,6-dihalophenylmethyl)-3,4-dihydropyrimidin4(3H)-ones: novel potent and selective dihydro-alkoxy-benzyl-oxopyrimidine derivatives. J. Med. Chem. 1999, 42, 619-627. [CrossRef] [PubMed]

18. Zaton, A.M.; Villamor, J.P. Study of heterocycle rings binding to human serum albumin. Chem. Biol. Interact. 2000, 124, 1-11. [CrossRef]

19. Selassie, C.D.; Gan, W.X.; Kallander, L.S.; Klein, T.E. Quantitative structure-activity relationships of 2,4-Diamino-5-(2-X-benzyl)pyrimidines versus bacterial and avian dihydrofolate reductase. J. Med. Chem. 1998, 41, 4261-4272. [CrossRef] [PubMed]

20. Herrera, A.; Martínez-Álvarez, R.; Ramiro, P.; Chioua, M.; Torres, R. On the mechanism of reaction between ketones and nitriles. Unexpected results from benzyl nitriles. Tetrahedron 2002, 58, 3755-3764. [CrossRef]

21. Tanaka, H.; Takashima, H.; Ubasawa, M.; Sekiya, K.; Inouye, N.; Baba, M.; Shigeta, S.; Walker, R.T.; De Clercq, E.; Miyasaka, T. Synthesis and antiviral activity of 6-benzyl analogs of 1-[(2-hydroxyethoxy) methyl]-5-(phenylthio)thymine (HEPT) as potent and selective anti-HIV-1 agents. J. Med. Chem. 1995, 38, 2860-2865. [CrossRef] [PubMed] 
22. Li, D.L.; Li, X.M.; Li, T.G.; Dang, H.Y.; Wang, B.G. Dioxopiperazine alkaloids produced by the marine mangrove derived endophytic fungus Eurotium rubrum. Helv. Chim. Acta 2008, 91, 1888-1893. [CrossRef]

23. Zhou, L.N.; Zhu, T.J.; Cai, S.X.; Gu, Q.Q.; Li, D.H. Three new indole-containing diketopiperazine alkaloids from a deep-ocean sediment derived fungus Penicillium griseofulvum. Helv. Chim. Acta 2010, 93, 1758-1763. [CrossRef]

24. Ye, W.C.; Wang, G.C.; Li, T.; Huang, X.J. Whitmanoside A, a new $\alpha$-pyrone glycoside from the Leech Whitmania pigra. Heterocycles 2013, 87, 1537-1543.

25. Wang, W.L.; Zhu, T.J.; Tao, H.W.; Lu, Z.Y.; Fang, Y.C.; Gu, Q.Q.; Zhu, W.M. Three novel, structurally unique spirocyclic alkaloids from the halotolerant B-17 fungal strain of Aspergillus variecolor. Chem. Biodivers. 2007, 4, 2913-2919. [CrossRef] [PubMed]

26. Skehan, P.; Storeng, R.; Scudiero, D.; Monks, A.; McMahon, J.; Vistica, D.; Warren, J.T.; Bokesch, H.; Kenney, S.; Boyd, M.R. New colorimetric cytotoxicity assay for anticancer-drug screening. J. Natl. Cancer Inst. 1990, 82, 1107-1112. [CrossRef] [PubMed]

27. Frisch, M.J.; Trucks, G.W.; Schlegel, H.B.; Scuseria, G.E.; Robb, M.A.; Cheeseman, J.R.; Scalmani, G.; Barone, V.; Mennucci, B.; Petersson, G.A.; et al. Gaussian 09; Revision C.01; Gaussian, Inc.: Wallingford, CT, USA, 2010.

28. Schäfer, A.; Huber, C.; Ahlrichs, R. Fully optimized contracted Gaussian basis sets of triple zeta valence quality for atoms Li to Kr. J. Chem. Phys. 1994, 100, 5829-5835. [CrossRef]

29. Bruhn, T.; Schaumlöffel, A.; Hemberger, Y.; Bringmann, G. SpecDis: Quantifying the comparison of calculated and experimental electronic circular dichroism spectra. Chirality 2013, 25, 243-249. [CrossRef] [PubMed]

30. Elshahawi, S.I.; Cao, H.; Shaaban, K.A.; Ponomareva, L.V.; Subramanian, T.; Farman, M.L.; Spielmann, H.P.; Phillips, G.N., Jr.; Thorson, J.S.; Singh, S. Structure and specificity of a permissive bacterial C-prenyltransferase. Nat. Chem. Biol. 2017, 13, 366-368. [CrossRef] [PubMed]

31. Wong, C.P.; Awakawa, T.; Nakashima, Y.; Mori, T.; Zhu, Q.; Liu, X.; Abe, I. Two distinct substrate binding modes for the normal and reverse prenylation of hapalindoles by the prenyltransferase AmbP3. Angew. Chem. Int. Ed. 2018, 57, 560-563. [CrossRef] [PubMed] 